\title{
YEASTS ISOLATED FROM CLINICAL SAMPLES OF AIDS PATIENTS
}

\author{
Rejane Pereira Neves; Maria Auxiliadora de Q. Cavalcanti*; Guilherme Maranhão Chaves; Oliane M.C. Magalhães
}

Departamento de Micologia, Centro de Ciências Biológicas, Universidade Federal de Pernambuco, Recife, PE, Brasil

Submitted: January 30, 2002; Returned to authors for corrections: April 18, 2002; Approved: December 05, 2002.

\section{SHORT COMMUNICATION}

\begin{abstract}
In order to investigate yeasts in oropharyngeal secretion, urine, sputum and inguinal scales from AIDS patients, clinical samples were collected from one hundred patients interned in the Infectious and Parasitic Diseases Sector of the Hospital das Clínicas of the Universidade Federal de Pernambuco and in Hospital Universitário Osvaldo Cruz of the Universidade de Pernambuco. Yeasts were isolated from seventy-two out of one hundred and eight clinical samples. The isolated yeasts were: Candida albicans (sixty-two isolates), Candida tropicalis (four isolates), Candida glabrata (two isolates), Candida parapsilosis (two isolates), Candida krusei (one isolate) and Trichosporon pullulans (one isolate).
\end{abstract}

Key words: Yeasts, AIDS, Candida spp.

Fungi and other microorganisms are present in the oral cavity and also in mucous inflammatory lesions (5). The isolation of species of Candida in oral candidiasis has been shown to increased with the advance of HIV infection.

C. albicans has been isolated from various sources $(3,20)$, and is considered to be the most pathogenic species and frequently isolated from oral diseases in immunocompromised individuals (13). However, over the past decades the incidence of infections caused by other Candida species including $C$. tropicalis, $C$. glabrata, $C$. krusei and other genera such as Trichosporon and Cryptococcus has been reported $(6,9,21)$. However, infections caused by Trichosporon are rare (18).

Considering the increasing number of cases of AIDS in Pernambuco, Brazil, and the susceptibility to opportunistic mycosis, the objective of this study was to isolate and identify yeasts in clinical samples of AIDS patients.

From one hundred AIDS patients (75 male and 25 female), interned at the Sector of Infectious and Parasitic Diseases (DIP) of the Hospital das Clínicas (Universidade Federal de Pernambuco) and Hospital Universitário Osvaldo Cruz (Universidade de Pernambuco), 108 clinical samples (95 from the oropharyngeal secretion, 11 from urine, one sputum and one from inguinal scale) were collected. The samples were spread on Petri dishes containing Sabouraud agar medium with $50 \mathrm{mg} / \mathrm{l}$ of yeast extract and $50 \mathrm{mg}$ chloramphenicol/l (10) and maintained at room temperature $\left(28^{\circ} \mathrm{C} \pm 1^{\circ} \mathrm{C}\right)$. The growth of the cultures was monitored for 15 days, when the colonies were transferred to tubes with Sabouraud agar medium and maintained at room temperature.

The strains were identified according to Barnett et al. (1), Kreger-van Rij (8) and Lodder (11) and by assimilation patterns, using the comercial kit CANDIFAST - REF. 44008 (Interlab).

Seventy-two strains of yeasts, 69 from oropharingeal secretion, one from urine, one from sputum and one from inguinal scale, were isolated. The failure to isolate yeasts from the remaining 36 clinical samples was probably due to the presence of fast growing chloramphenicol resistant bacteria.

The isolated yeasts strains were identified as $C$. albicans (sixty-two strains), C. tropicalis (four strains), C. glabrata (two strains) and C. parapsilosis (two strains), C. krusei (one strain) and Trichosporon pullulans (one strain). The results show predominance of $C$. albicans in oropharyngeal candidiasis in

\footnotetext{
* Corresponding author. Mailing address: Av. Boa Viagem, 3376/92. Boa Viagem, Recife, PE, Brasil. 51020-001. Fax: (+5581) 3271-8482. E-mail: xiliamac@terra.com.br
} 
AIDS patients, as also mentioned by other authors $(2,4,9,10)$. The other species also cause mycosis under favorable conditions, and have also been isolated from AIDS patients $(12,14,15,17)$.

Trichosporon pullulans, isolated from oropharingeal secretion, was reported in leukaemia patients with lung infection (18), and blood cancer patients using a catheter (9). Despite being known as an etiological agent of mycosis in immunocompromised individuals with other pathologies $(9,18)$, this is probably the first citation of T. pullulans in AIDS patients. The comensal nature of Candida species emphasizes the opportunistic characteristics of oral candidiasis since they are observed in approximetely $50 \%$ of healthy individuals $(16,19)$.

\section{RESUMO}

\section{Leveduras isoladas de materiais clínicos de pacientes com AIDS}

Para investigar leveduras em amostras clínicas de secreção orofaríngea, urina, esputo e escamas inguinais em pacientes com AIDS, foram realizadas coletas em 100 pacientes internos no setor de Doenças Infecciosas e Parasitárias do Hospital das Clínicas da Universidade Federal de Pernambuco e do Hospital Universitário Osvaldo Cruz da Universidade de Pernambuco. Foram isoladas leveduras em setenta e duas amostras clínicas, sendo sessenta e duas de Candida albicans, quatro de $C$. tropicalis, duas de C. glabrata, duas de C. parapsilosis, uma de $C$. krusei e uma de Trichosporon pullulans.

Palavras-chave: Leveduras, AIDS, Candida spp.

\section{REFERENCE}

1. Barnett, J.A.; Paine, R.W.; Yarrow, D. Yeasts: Characteristics and identification. University Press, Cambridge, 1990, 1002p.

2. Bossche, H.V.; Mackenzie, D.W.R.; Cauwembergh, G.; Cutsem, J.W.; Drouhet, E.; Dupon, B. Mycoses in AIDS patients. Plenum Press, New York, 1990, 337p.

3. Chaffin, W.L., López-Ribot, J.L.; Casanova, M.; Gozalbo, D. Martínez, J.P. Cell wall and secreted protens of Candida albicans: Identification, function and expression. Microbiol Mol. Biol. Rev., 62: $130-180,1998$.
4. De Vita Jr.; T.V.; Hellman, S.; Rosemberg, S.A. AIDS, SIDA etiologia diagnose, tratamento e prevenção. Revinter, Rio de Janeiro, 1991, $485 \mathrm{p}$.

5. Glowacta, A.; Bialasiewicz, D.; Kurnatowska, A. Activity of selected hydrolytic enzymes of fungi, Mikol. Lek., 2: 83-88, 1995

6. Jarvis, W.R. Epidemiology of nosocomial fungal infections, with emphasis on Candida species. Clin. Infect. Dis., 20: 1526-1530, 1995.

7. Korting, H.C.; Ollert, M.; Georgii, A.; Froschl, M. In vitro susceptibilities and byotypes of Candida albicans isolates from the oral cavities of patients infected with human immunodeficiency virus. J. Clin. Microbiol., 26: 2626-2631, 1988.

8. Kreger-van Rij, N.J.W. The yeast: a taxonomic study. Elsevier Sci. Publication, Amsterdan, 1984, 1091p.

9. Kremery, V. Jr.; Mateicka, F.; Kunova, A.; Spanik, S.; Giarfas, J.; Sycova, Z.; Trupl, J. Hematogenous trichosporonosis in cancer patients: report of 12 cases including 5 during prophylaxis with itraconazol. Support Care Cancer, 7: 39-43, 1999.

10. Lacaz, C.S.; Porto, C.; Martins, J.E.C. Micologia Médica: fungos, actinomycetes e algas de interesse médico. Sarver-EDUSP, São Paulo, 1991, 695p

11. Lodder, J. The Yeast: a taxonomic study. North Holland Publishing Company, Oxford, 1970, 1385p.

12. Mccullough, M., Humet, S. A longitudinal study of the change in resistance patterns and genetic relationship of oral Candida albicans from HIV-infected patients. J. Med. Vet. Mycol., 33: 33 37, 1995.

13. Odds, F.C.; Schmid, J.; Soll, D.R. Epidemiology of Candida infection in AIDS. In Vanden Bossche, H. Mycoses in AIDS patients. Plenum Press, New York, 1990, p.67-74.

14. Pujol, C.; Renauld, F.; Mallie, M.; Meeús, T.; Bastide, J. M. Atypical strains of Candida albicans recovered from AIDS patients. J. Med. Vet. Mycol., 35: 115-121, 1997.

15. Reade, P.C. Candida albicans morphotypes in HIV infections, $J$. Med. Vet. Mycol., 31: 289-297, 1993

16. Samaranayake, L.P; Holmstrup, P. Oral candididiasis and human immunodeficiency virus infection. J. Oral Pathol. Med., 18: 554564, 1989.

17. Scully, C.; El-Kabir, M.; Samaranayake, L.P. Candida and ora candidosis: a review. Crit. Rev. Oral Biol. Med., 5: 125-157, 1994.

18. Shigehara, K.; Takahashi, K.; Tsunematsu, K.; Koba, H.; Katoh, S.; Asakawa, M.; Suzuki, A. A case of Trichosporon pullulans infection of the lung with adult T-cell leukemia. J. Med., 2: 135$137,1991$.

19. Soll, D.R.; Galask, R.; Schimid, J. Genetic dissimilarity of commensal strains of Candida spp. carried in different anatomical locations of the same healthy women. J. Clin. Microbiol., 29: 1702-1710, 1991.

20. Torssander, J.; Morfeldt-Manson, L.; Biberfeld, G.; Karlsson, A.; Putkonen, P.O.; Wasserman, J. Oral Candida albicans in HIV infection. Scand. J. Infect. Dis., 19: 291-295,1987.

21. Wingard, J.R. Importance of Candida species other than C. albicans as pathogens in oncology patiens. Clin. Infect. Dis., 20: 115-125, 1995 . 